\title{
NUTRITIONAL PATTERNS IN CHRONIC KIDNEY DISEASE
}

\author{
Andreea MIHALACHE ${ }^{1 凶}$, Liliana GARNEATA ${ }^{2}$, Gabriel MIRCESCU ${ }^{2}$ \\ ${ }^{1}$ Department of Cardiology, „Carol Davila“ University of Medicine and Pharmacy, „Sf. Ioan“ Emergency \\ Clinical Hospital, Bucharest, Romania \\ ${ }^{2}$ Department of Nephrology, „Carol Davila“ University of Medicine and Pharmacy, „Dr. Carol Davila“ \\ Teaching Hospital of Nephrology, Bucharest, Romania
}

Received 11 June 2018, Accepted 04 Aug 2018

https://doi.org/10.31688/ABMU.2018.53.3.18

\begin{abstract}
Chronic kidney disease (CKD) is a public health problem due not only to the heavy burden of renal replacement therapy, but also to the increased cardiovascular risk and higher mortality. Emerging evidence suggests that dietary patterns play a more significant role than the nutrients in CKD. Thus, several macronutrients, especially high protein intake, could be risk factors for $\mathrm{CKD}$, while a vegetarian, Mediterranean or a Dietary Approaches to Stop Hypertension (DASH) diet could be at least as effective as protein restriction in reducing CKD progression. This review summarizes both the association between several macro-/micronutrients and CKD, and the existing data on the relationship between dietary patterns and renal outcome.
\end{abstract}

Keywords: nutrition, chronic kidney disease, dietary patterns.

\section{Abbreviations:}

CKD - chronic kidney disease

eGFR - estimated glomerular filtration rate

RRT - renal replacement therapy

DASH - Dietary Approaches to Stop Hypertension

\section{Résumé}

Modèles nutritionnels dans la maladie rénale chronique

La maladie rénale chronique est un problème de santé publique lié non seulement à la difficulté du traitement de remplacement rénal, mais également au risque cardiovasculaire accru et à la mortalité plus élevée. Des données émergentes suggèrent que les habitudes alimentaires jouent un rôle plus important que les aliments dans la maladie rénale chroniques. Ainsi, plusieurs macro produits nutritionnels, en particulier un apport élevé en protéines, pourraient constituer des facteurs de risque d'IRC, alors qu'un régime végétarien, méditerranéen ou DASH pourrait être au moins aussi efficace qu'une restriction protéique pour réduire la progression de l'IRC. Cette revue résume l'association entre plusieurs macro-/ micro produits nutritionnels et l'IRC, ainsi que les données existantes sur la relation entre les habitudes alimentaires et l'évolution de la maladie rénale

Mots-clés: nutrition, maladie rénale chronique, régimes alimentaires. 
KA - ketoanalogues

LPD - low protein diet

VLPD - very low protein diet

NNT - number needed to treat

DM - diabetes mellitus

BP - blood pressure

DBP - diastolic blood pressure

SBP - systolic blood pressure

DB PR - double-blind prospective randomized

PR - prospective randomized

RAAS - renin angiotensin aldosterone system

\section{INTRODUCTION}

Chronic kidney disease (CKD) is a public health problem. Patients with CKD have a higher mortality than the general population, particularly because of increased cardiovascular morbidity and mortality. In addition, they are at risk of progression towards dialysis and renal transplantation. Many of the risk factors for the development and progression of CKD are common with those of cardiovascular disease, and are related to the lifestyle. The current treatment guidelines for CKD recommend changes in diet and lifestyle, however, these recommendations are general, mainly based on observational studies, and the optimal dietary approach of CKD is not clear, yet. However, understanding the nutritional particularities of the patient with CKD is extremely important, as it can lead to effective therapeutic strategies.

\section{The ROLE OF DIETARY COMPONENTS IN CKD}

\section{Protein intake}

The protein restriction in CKD is indicated starting at a glomerular filtration rate below $60 \mathrm{ml} /$ $\min / 1.73 \mathrm{~m}^{2}{ }^{1}$. There are studies suggesting a more pronounced effect of low protein diets (LPDs) (less than $0.6 \mathrm{~g} / \mathrm{kg}$ day), with a good safety profile for patients. Even so, the largest study so far, Modification of Diet in Renal Disease (MDRD), did not initially show a significant decrease in renal function decline between patients with LPD $(0.58 \mathrm{~g} / \mathrm{kg}$ day $)$ and those with protein intake of $1.3 \mathrm{~g} / \mathrm{kg}$ day ${ }^{2}$. Neither the second phase of the study, which included 255 patients with more advanced CKD (GFR of $19 \mathrm{ml} / \mathrm{min} / 1.73 \mathrm{~m}^{2}$ ) who received a low-protein diet or a very low-protein diet (VLPD) $(0.3 \mathrm{~g} / \mathrm{kg}$ day) supplemented with ketones of key amino acids, showed any significant benefit ${ }^{3}$. However, there were enough limitations of this study. Very few diabetic patients were included in the study and the analysis made during the study did not consider the nature of ingested proteins (animal versus plant origin) or the adherence of patients to the LPD. In addition, the primary end-point was the variation of estimated glomerular filtration rate (eGFR) and not the initiation of dialysis or death.

Most systematic analysis suggest a benefit of protein restriction. For example, a Cochrane meta-analysis showed the protective renal effect of a moderate protein restriction diets ${ }^{4}$. The protein restriction decreased by $32 \%$ the number of patients who reached the primary end-point (death of any cause, initiation of renal replacement therapy or renal transplantation). Moreover, the number of patients who needed to be treated for one year (NNT) to avoid reaching the composite primary end-point death or initiation of renal substitution treatment ranged between two ${ }^{5}$ and fifty six ${ }^{2}$. In sub-analysis, there was a renal protective effect increased by $37 \%$ for a lower protein intake (7 studies compared an intake of $0.3-0.6 \mathrm{~g} / \mathrm{kg}$ day of protein with a higher one) $)^{4}$ (Table 1).

The nature of proteins is also important. The predominantly vegetal protein diet reduces proteinuria, decreases the production of uremic toxins, decreases phosphorus intake and endogenous acid production. Several mechanisms have been proposed to explain the potential benefits of plant proteins, one being the difference in the composition of essential amino acids. Also important are the metabolic effects on lipids and uric acid levels. An animal protein diet increases endogenous acid production and is the main source of phosphorus in the diet ( $>50 \%)$.

A prospective randomized study compared a very low protein diet (VLPD) $(0.3 \mathrm{~g} / \mathrm{kg}$ day), mainly of vegetable origin, supplemented with ketoanalogues, with a LPD ( $0.6 \mathrm{~d} / \mathrm{kg}$ day) (plant and animal proteins) in 207 patients with advanced chronic kidney disease (CKD) ${ }^{6}$. As compared to the LPD group, fewer patients in the ketoanalogues-supplemented group required renal replacement therapy (RRT) $(13 \%$ versus $42 \%, p<0.001)$. In another study, a diet rich in plant proteins was associated with a $23 \%$ lower mortality in CKD patients? 
Table 1. Studies evaluating the effects of low protein diets in patients with CKD

\begin{tabular}{|c|c|c|c|c|c|}
\hline \multirow{2}{*}{ Study (year) } & Study type & \multirow{2}{*}{ eGFR } & \multirow{2}{*}{ Intervention } & \multirow{2}{*}{ Parameter } & \multirow{2}{*}{ Results } \\
\hline & $N$ & & & & \\
\hline \multirow[b]{2}{*}{ Klahr $(1994)^{2}$} & $\mathrm{R}$ & \multirow{2}{*}{$\begin{array}{l}1: 22-55 \\
2: 13-24\end{array}$} & 1: Normoprotein diet & \multirow[b]{2}{*}{$\begin{array}{l}\text { Rate of GFR } \\
\text { decline }\end{array}$} & \multirow[b]{2}{*}{$\begin{array}{l}\text { Rate of GFR decline was not lower } \\
\text { in LPD than in normoprotein diet }\end{array}$} \\
\hline & $\begin{array}{l}1: 585 \\
2: 255\end{array}$ & & $\begin{array}{c}\text { vs. LPD } \\
\text { 2: LPD vs. VLPD + KA }\end{array}$ & & \\
\hline Kopple $(1997)^{3}$ & & alysis of $\mathrm{p}$ & evious study data & $\begin{array}{c}\text { Nutritional status, } \\
\text { hospitalization, } \\
\text { mortality } \\
\end{array}$ & $\begin{array}{l}\text { The LPD has a good safety profile } \\
\text { in CKD: no significant differences } \\
\text { between groups }\end{array}$ \\
\hline \multirow{2}{*}{$\begin{array}{l}\text { Aparicio } \\
(2000)^{32}\end{array}$} & $\mathrm{R}$ & \multirow{2}{*}{$\leq 25$} & \multirow{2}{*}{ VLPD-veg + KA } & \multirow{2}{*}{ Nutritional status } & \multirow{2}{*}{$\begin{array}{l}\text { VLPD did not alter the nutritional } \\
\text { status or the prognosis after RRT } \\
\text { initiation }\end{array}$} \\
\hline & 239 & & & & \\
\hline \multirow{2}{*}{$\begin{array}{l}\text { Bernhard } \\
(2000)^{33}\end{array}$} & $\mathrm{R}$ & \multirow{2}{*}{$\approx 30$} & \multirow{2}{*}{$\mathrm{LPD} \pm \mathrm{KA}$} & \multirow{2}{*}{$\begin{array}{l}\text { Leucine oxidation, } \\
\text { acidosis }\end{array}$} & \multirow{2}{*}{$\begin{array}{l}\text { LPD is metabolically safe in patients } \\
\text { with CKD }\end{array}$} \\
\hline & 12 & & & & \\
\hline \multirow{2}{*}{$\begin{array}{l}\text { Cianciaruso } \\
(2007) \\
34\end{array}$} & $\mathrm{R}$ & \multirow[b]{2}{*}{$18 \pm 7$} & \multirow[b]{2}{*}{ LPD vs. NP } & \multirow[b]{2}{*}{ BUN } & \multirow{2}{*}{$\begin{array}{l}\text { Lower BUN in LPD; } \\
\text { Reduced compliance to diet in the } \\
\text { LPD group }\end{array}$} \\
\hline & 300 & & & & \\
\hline \multirow{2}{*}{$\begin{array}{l}\text { Bellizzi } \\
(2007)^{35}\end{array}$} & I & \multirow[b]{2}{*}{$<30$} & \multirow{2}{*}{$\begin{array}{l}\text { VLPD supplemented } \\
\text { with KA vs. LPD vs NP } \\
\text { diet } \\
\end{array}$} & \multirow[b]{2}{*}{ Blood pressure } & \multirow{2}{*}{$\begin{array}{l}\text { The blood pressure declined only in } \\
\text { the VLPD group, despite the reduced } \\
\text { need of antihypertensives }\end{array}$} \\
\hline & 110 & & & & \\
\hline \multirow{2}{*}{$\begin{array}{l}\text { Chauveau } \\
(2009)^{36}\end{array}$} & $\mathrm{O}$ & \multirow{2}{*}{$<30$} & \multirow{2}{*}{$\begin{array}{l}\text { VLPD-veg }(0.3 \mathrm{~g} / \mathrm{kg} / \\
\text { day }+\mathrm{KA}\end{array}$} & \multirow{2}{*}{$\begin{array}{l}\text { Mortality after } \\
\text { RRT }\end{array}$} & \multirow{2}{*}{$\begin{array}{l}\text { Similar survival rates in VLPD pts } \\
\text { and in the French dialysis registry } \\
\text { pts. }\end{array}$} \\
\hline & 203 & & & & \\
\hline \multirow{2}{*}{$\begin{array}{c}\text { Gărneață } \\
(2015)^{6}\end{array}$} & $\mathrm{R}$ & \multirow{2}{*}{$<30$} & YI PD & IN & NNT to avoid dialysis or a $50 \%$ \\
\hline & 207 & & VLFD-veg + KA VS. LID & NNI & eGFR \\
\hline Piccoli & $\mathrm{O}$ & $\approx 2$ & $D M$ ve non-DM & RRT initi & Similar efficiency in diabetic and \\
\hline$(2016)^{37}$ & 449 & $\approx 20$ & LPD in DM Vs. non-DM & KKI initiation & \\
\hline Chen $(2016)^{7}$ & $\mathrm{O}$ & NA & Vegetal proteins vs. & Mortality & Vegetal protein diet is associated \\
\hline & 14866 & & animal proteins & & with a lower mortality risk \\
\hline
\end{tabular}

eGFR - mL/min $1,73 \mathrm{~m}^{2}$

Type of study: I - interventional, $\mathrm{R}$ - randomized; $\mathrm{O}$ - observational ; $\mathrm{N}$ - number of participants

BUN - Blood urea nitrogen; KA - ketoanalogues; LPD - low protein diet; RRT - renal replacement therapy; VLPD - very low protein diet; VLPD-veg - very low protein vegetarian diet; NP - normoprotein diet; NNT - number needed to treat,

DM - diabetes mellitus

\section{Energy demand}

The nutritional status is very important in CKD patients, especially in the latter stages, the energy and protein intake being the most important determinant. An appropriate caloric intake can improve protein use and reduce protein catabolism in patients with CKD. The optimal energy input in patients with CKD is, according to the KDOQI Guidelines, $35 \mathrm{kcal} / \mathrm{kg} /$ day in patients under 60 years and $30-35 \mathrm{kcal} / \mathrm{kg} / \mathrm{day}$ in those over 60 years ${ }^{8}$. In non-diabetic patients, the glomerular filtration rate (eGFR) was lower in those on a diet with high protein but with inadequate caloric intake than in those on a low protein diet with adequate caloric intake $\left(24.5 \pm 16.3 \mathrm{ml} / \mathrm{min} / 1.73 \mathrm{~m}^{2}\right.$ vs. $\left.32.7 \pm 17.3 \mathrm{ml} / \mathrm{min} / 1.73 \mathrm{~m}^{2}, \mathrm{p}=0.002\right)^{9}$.

\section{Lipid intake}

Patients with CKD show alterations in the serum lipid profile which differ from those in the general population. A recent study showed that, although the total cholesterol was low in patients with CKD, the triglyceride elevation, VLDL and HDL cholesterol decrease were responsible for cardiovascular events ${ }^{10}$.

Dyslipidemia is considered a risk factor for CKD progression, with several observational studies demonstrating that lipid abnormalities are correlated with a decrease in the glomerular filtration rate in the general population. Guidelines recommend that $<30 \%$ of the daily caloric intake should come from lipids, focusing on the "healthy" fat sources. The optimal distribution among classes of fatty acids is not yet determined. However, the increased intake of omega- 3 and monounsaturated fatty acids appears to have a beneficial effect on CKD progression.

Food fiber intake and impact on the microbiome

The intestinal microbiome carries essential metabolic functions and has a key role in the maturation and modulation of the immune system. The microbiome shows alterations starting from the first CKD 
stages. Uremic patients have an increased number of bacteria in the duodenum and jejunum, areas that are otherwise poorly colonized in healthy individuals. In addition, patients with CKD exhibit qualitative changes in the microbiome. The CKD-associated factors, such as metabolic acidosis, intestinal edema or increased uremic toxin levels, are involved in the development of dysbiosis. Moreover, drugs (antibiotics, proton pump inhibitors and iron supplements) and dietary restrictions (reduced dietary fiber intake) further alter the microbiome.

The amount of fiber recommended for patients with a GFR below $60 \mathrm{ml} / \mathrm{min} / 1.73 \mathrm{~m}^{2}$ is between $5-38 \mathrm{~g} /$ day, as in the general population. The best sources of fiber are legumes (beans and peas), but also nuts, fruits, and whole grains. Numerous studies have shown a protective effect on cardiovascular disease, diabetes, cancer or all-cause mortality in the general populations. Effects appear to be even more important in patients with $\mathrm{CKD}$, perhaps due to the association of increased fiber intake with decreased inflammation. An observational study conducted on 14,543 participants compared the effects of a $10 \mathrm{~g} /$ day fiber intake in patients with and without CKD. The reduction in reactive $\mathrm{C}$ protein levels in $\mathrm{CKD}$ patients was $38 \%$, compared to $11 \%$ in the general population ${ }^{11}$.

\section{Sodium intake}

Information on salt intake comes mostly from studies in hypertension. However, the increased dietary sodium intake has effects beyond blood pressure and are independent of extracellular fluid expansion. Excessive sodium intake is correlated with a multitude of CKD progression factors and cardiovascular risk factors such as hypertension, water retention, proteinuria, inflammation, oxidative stress and endothelial dysfunction.

The reduction of blood pressure is significant in patients with CKD. A decrease in salt intake to $6 \mathrm{~g} /$ day $(2300 \mathrm{mg} \mathrm{Na})$ results in a decrease in blood pressure by $9 / 4 \mathrm{mmHg}^{12}$. The reduction is more significant in studies where dietary interventions lasted over 4 weeks. Sodium restriction also has an important effect on proteinuria, with some studies reporting a decrease of up to $51 \%$ of albuminuria ${ }^{13}$. The decrease was significantly higher in patients with CKD than in the general population, suggesting an increased susceptibility in this group of patients ${ }^{14}$.

\section{Potassium intake}

Potassium is critical for the normal cell function. The kidney plays an essential role in maintaining the balance between the potassium intake and urinary excretion. In the general population, potassium is associated with decreased blood pressure, promoting natriuresis and diuresis ${ }^{15}$. Data from the literature on the effect of dietary potassium intake on CKD progression are contradictory. A study conducted on a cohort of 2929 patients with CKD showed an association between elevated urinary excretion of sodium and potassium and an increased risk of CKD progression ${ }^{16}$. Instead, another study conducted on a cohort from 17 countries showed an association between high urinary potassium excretion and decreased mortality and cardiovascular events ${ }^{17}$.

\section{Phosphorus intake}

An elevated serum phosphorus level is associated with an increased risk of cardiovascular events and mortality in CKD patients. There are studies suggesting a role in the progression of $\mathrm{CKD}$, but a study in a cohort of 10,672 patients did not confirm this association ${ }^{18}$. However, a recent meta-analysis suggests an independent relationship between serum phosphorus levels, renal failure, and mortality in non-dialyzed patients $\mathrm{CKD}^{19}$.

In CKD patients, the increased dietary phosphorus can aggravate the hyperparathyroidism and renal osteodystrophy. What also matters, however, is the type of phosphorus in the diet (organic/anorganic), the source (plant/animal) and the phosphorus/ protein ratio. The main sources of phosphorus are the dairy products, meat and fish. Many food additives contain a high amount of phosphorus, which significantly increases the intake of phosphorus in a Western diet. These additives are added to most processed foods, including acidified beverages, meat products, cheese, sauces, cereals, bars and pastries.

\section{The calcium intake}

Both high and low levels of calcium are associated with high mortality in patients with CKD. Calcium deficiency is a stimulus for secondary hyperparathyroidism, with bone demineralization, while excess of calcium is involved in extra-skeletal (vascular) calcifications. Unfortunately, there are no randomized studies to determine the optimal calcium intake in pre-dialysis CKD patients.

\section{Nutritional patterns in CKD}

The available data suggest that certain nutrients may influence CKD progression and occurrence of its complications. Thus, dietary therapy can be an essential part of CKD's therapeutic program. The current approach, focused on the control of caloric intake and macro- or micro-nutrients, is, however, difficult to understand and quantify by patients. The low compliance with dietary recommendations 
Table 2. Studies analyzing the effects of a nutritional pattern in CKD

\begin{tabular}{|c|c|c|c|c|}
\hline \multirow{2}{*}{ Study (year) } & Study type & \multirow[t]{2}{*}{ eGFR } & \multirow{2}{*}{ Nutritional pattern } & \multirow{2}{*}{ Results } \\
\hline & $\mathrm{N}$ & & & \\
\hline \multirow{2}{*}{$\begin{array}{l}\text { Gutiérrez } \\
(2014)^{24}\end{array}$} & $\mathrm{O}$ & \multirow{2}{*}{$<60$} & \multirow{2}{*}{ „Southern“ diet vs. plant-based } & \multirow{2}{*}{$\begin{array}{l}\text { A diet rich in fruits and vegetables was associ- } \\
\text { ated mortality by } 33 \%\end{array}$} \\
\hline & 3972 & & & \\
\hline \multirow{2}{*}{ Rebholz $(2016)^{21}$} & $\mathrm{O}$ & \multirow{2}{*}{$\geq 60$} & \multirow{2}{*}{ DASH Diet } & \multirow{2}{*}{$\begin{array}{l}\text { Low DASH diet score had higher risk to } \\
\text { develop CKD }\end{array}$} \\
\hline & 15792 & & & \\
\hline \multirow{2}{*}{ Asghari $(2017)^{38}$} & $\mathrm{O}$ & \multirow{2}{*}{$\geq 60$} & \multirow{2}{*}{ DASH Diet } & \multirow{2}{*}{$\begin{array}{l}\text { Adherence to a DASH diet is associated with } \\
\text { a decrease in CKD incidence }\end{array}$} \\
\hline & 1630 & & & \\
\hline \multirow{2}{*}{$\operatorname{Lin}(2011)^{20}$} & $\mathrm{O}$ & \multirow{2}{*}{ NA } & \multirow{2}{*}{$\begin{array}{c}\text { „Western“ diet vs a DASH-type } \\
\text { diet }\end{array}$} & \multirow{2}{*}{$\begin{array}{l}\text { "Western" diet associated with a higher risk of } \\
\text { microalbuminuria and GFR decline. }\end{array}$} \\
\hline & 3121 & & & \\
\hline \multirow{2}{*}{ Scialla $(2012)^{39}$} & $\mathrm{O}$ & & \multirow{2}{*}{$\begin{array}{l}\text { Diet with high endogenous pro- } \\
\text { duction of acids }\end{array}$} & \multirow{2}{*}{$\begin{array}{c}\text { Diets with high acid production are associated } \\
\text { with a faster decline in GFR. }\end{array}$} \\
\hline & 632 & & & \\
\hline \multirow{2}{*}{$\begin{array}{l}\text { Krishnamurthy } \\
\quad(2012)^{11}\end{array}$} & $\mathrm{O}$ & \multirow[b]{2}{*}{$<60$} & \multirow[b]{2}{*}{ Diet rich in plant fibers } & \multirow{2}{*}{$\begin{array}{l}\text { Each increase of } 10 \mathrm{~g} / \text { day of fiber intake } \\
\text { decreased inflammation, more frequent in } \\
\text { CKD patients }\end{array}$} \\
\hline & 14533 & & & \\
\hline \multirow{2}{*}{$\begin{array}{c}\text { Díaz-López } \\
(2012)^{40}\end{array}$} & $\mathrm{R}$ & \multirow{2}{*}{ NA } & \multirow{2}{*}{$\begin{array}{l}\text { MedD with olive oil vs MedD } \\
\text { with nuts vs low lipid diet. }\end{array}$} & \multirow{2}{*}{$\begin{array}{l}\text { All dietary interventions similarly influenced } \\
\text { the GFR slope. }\end{array}$} \\
\hline & 870 & & & \\
\hline \multirow{2}{*}{ Chrysohoou $^{22}$} & $\mathrm{P}$ & & \multirow{2}{*}{ MedD } & \multirow{2}{*}{$\begin{array}{l}\text { Adherence to MedD is associated with de- } \\
\text { creased BUN }\end{array}$} \\
\hline & 3042 & & & \\
\hline & $\mathrm{O}$ & & MedD & HighMedD score is associated with a decrease \\
\hline $\mathrm{Kh}$ & 3298 & NA & & GFR decline \\
\hline & $\mathrm{O}$ & & & Consumption of plants is associated with \\
\hline Wai $(2017)^{25}$ & 145 & $15-59$ & $\begin{array}{l}\text { Consumption of fruits and veg- } \\
\text { etables and alcohol }\end{array}$ & $\begin{array}{c}\text { lower risks of mortality, dialysis or creatinine } \\
\text { doubling }\end{array}$ \\
\hline Gopinath & $\mathrm{O}$ & & Consumption of carbohydrate & High glycemic index is associated with \\
\hline$(2011)^{26}$ & 3654 & & and dietary fiber & $\begin{array}{l}\text { increased risk of GFR }<60 \mathrm{~mL} / \mathrm{min} \text { and in- } \\
\text { creased dietary fiber with decreased risk }\end{array}$ \\
\hline & $\mathrm{O}$ & & & The consumption of sweetened juices is as- \\
\hline $\begin{array}{l}\text { Domback } \\
(2010)^{41}\end{array}$ & 15745 & & Consumption of sweet drinks & $\begin{array}{c}\text { sociated with a } 40 \% \text { higher prevalence of a } \\
\text { GFR }<60\end{array}$ \\
\hline
\end{tabular}

Type of study: R - randomized; O - observational, eGFR - $\mathrm{mL} / \mathrm{min} / 1,73 \mathrm{~m}^{2}, \mathrm{~N}$ - number of participants, MedD Mediterranean diet

remains a challenge for clinicians. One of the solutions could be the use of nutritional models that treat nutrients and foods together aiming to lower the risk of progression and to improve the CKD prognosis. The concept of food synergy, developed over the last few years, argues that nutritional patterns have a greater impact on health rather than the use of individual foods or nutritional supplements. Thus, when considering the nutritional needs of patients with CKD, the focus should be on food.

Most of the proposed interventions rely on a predominantly vegetal diet with low animal and sodium protein content. Among the dietary patterns associated with a favorable prognosis in CKD are the DASH (Dietary Approaches to Stop Hypertension) and the Mediterranean diet $^{3}$. Their beneficial effect may be related to the impact on cardiovascular morbidity (Table 2).

\section{DASH (Dietary Approaches to Stop Hypertension)}

The DASH Diet is a food plan promoted by the US National Institutes of Health for the Prevention and Control of Hypertension. This diet involves an increased consumption of fruit and vegetables, whole grains, nuts and low-fat dairy products. It also has a low content in sodium, refined sugars, fat and red meat.

There are few studies that looked at the link between DASH and CKD. In the Nurses Health study, the risk of renal function loss in women with mild renal impairment was correlated with the Western diet. The DASH diet was associated with an almost 50\% lower risk of decline in renal function ${ }^{20}$. However, one of the limitations of this study was the cohort selection, i.e. older Caucasian women. A recent study in a large unselected cohort $(\mathrm{N}=14,882)$ concluded that the DASH diet is associated with a $16 \%$ lower risk of $\mathrm{CKD}$, regardless of the demographic characteristics, 
the presence of risk factors for CKD, or the level of renal function ${ }^{21}$.

\section{The Mediterranean diet}

Although it has many common features with the DASH diet, the Mediterranean diet is rather a lifestyle. The food component includes increased consumption of plant foods (whole grains, fruits, vegetables, nuts, seeds and olives), moderate consumption of eggs and dairy products and low consumption of red meat and alcohol. The main source of added fat is olive oil, which adds up to a great deal of fish and seafood consumption. Other components that make up this lifestyle are the use of small portions, socialization, moderate physical activity, rest and use of seasonal, traditional, local, biodivers foods, thus avoiding intensely processed foods.

The beneficial effect of the Mediterranean diet in reducing cardiovascular risk is already well known. Furthermore, it is associated with improving the prognosis of many chronic diseases, including depression, breast cancer and colorectal cancer, diabetes, obesity, asthma, erectile dysfunction, and dementia. Studies that looked at the effects of the Mediterranean diet showed a beneficial effect on kidney function. Increased adherence to the Mediterranean diet was associated with lower urea and creatinine levels and higher glomerular filtration rate ${ }^{22}$. A recent prospective observational study examined the correlation between degree of adherence to the Mediterranean diet and the long-term kidney function, reporting a significant reduction in the risk of CKD. Each 1-point increase in the median nutritional score for the Mediterranean diet was associated with a reduction in the incidence of a eGFR $<60 \mathrm{ml} / \mathrm{min} / 1.73 \mathrm{~m}^{2}$ (OR $0.83 ; 95 \% \mathrm{CI}, 0.71-0.96)^{23}$. One of the mechanisms involved may be the effect on endothelial dysfunction and inflammation, which are important components of CKD progression.

\section{Other nutritional models}

A study in a cohort of patients with CKD analyzed the connection between the nutritional patterns and the risk of mortality and progression of CKD. Western-diet - characterized by increased consumption of roasted foods, processed meat and sweet drinks - was correlated with a 1.5 higher mortality risk than other type of diet, e.g. diets based on increased consumption of fish, fruit and vegetables (HR 1.51; 95\% CI, 1.19-1.92) $)^{24}$. These results are supported by a recent Australian study showing that healthy eating habits, represented by adequate consumption of fruits and vegetables (HR 0.61; 95\% CI, 0.39-0.94) and limited alcohol consumption (HR 0.79; 95\% CI: $0.65-0.96)$ are associated not only with a lower risk to reach a renal composite end-point (doubling of serum creatinine or initiation of renal replacement therapy), but also with improved survival in CKD stage 3-4 patients: $0.35 ; 95 \% \mathrm{CI}, 0.15-0.83)^{25}$.

Consumption of grain or wholegrain bread fibers decreases the incidence of CKD, either by reducing the postprandial hyperglycemic peak, by lowering albuminuria, or by reducing other risk factors. On the other hand, the consumption of refined carbohydrates (e.g. carbonated beverages, cakes, sweets) is associated not only with a 3 -fold higher risk of kidney disease at 5 years but also with an increased prevalence of hyperuricemia and $\mathrm{CKD}^{26}$.

As for the alcohol consumption, there are mixed observations reported, some studies showing a correlation between the risk of developing and progression of chronic kidney disease and the increased alcohol consumption ${ }^{27-29}$. However, most studies have not found a significant link between moderate alcohol consumption and the progression of chronic kidney disease $e^{30,31}$.

\section{Conclusions}

The increasing incidence and prevalence of CKD needs the development of effective, patient-centered therapeutic strategies. Diet has a vital role in optimizing CKD prognosis by increasing the quality of life and decreasing morbidity. However, additional studies are necessary to establish the optimal nutritional interventions, focusing on the nutritional pattern rather than on nutrients.

\section{Compliance with Ethics Requirements:}

„The authors declare no conflict of interest regarding this article"

"No funding for this study“

\section{RefEREnCES}

1. NKF KDOQI Guidelines - https://www.kidney.org/professionals/guidelines

2. Klahr S, Levey AS, Beck GJ, et al. The effects of dietary protein restriction and blood-pressure control on the progression of chronic renal disease. Modification of Diet in Renal Disease Study Group. N Engl J Med 1994;330(13):877-84.

3. Kopple JD, Levey AS, Greene T, et al. Effect of dietary protein restriction on nutritional status in the Modification of Diet in Renal Disease Study. Kidney Int 1997;52(3):778-91.

4. Fouque D, Laville M, Boissel JP. Low protein diets for chronic kidney disease in non diabetic adults. Cochrane Database Syst Rev 2006;(2):CD001892

5. Di Iorio BR, Minutolo R, De Nicola L, et al. Supplemented very low protein diet ameliorates responsiveness to erythropoietin in chronic renal failure. Kidney Int 2003;64(5):1822-8. 
6. Garneata L, Stancu A, Dragomir D, Stefan G, Mircescu G. Ketoanalogue-supplemented vegetarian very low-protein diet and CKD progression. J Am Soc Nephrol 2016;27(7):2164-76.

7. Chen X, Wei G, Jalili T, et al. The associations of plant protein intake with all-cause mortality in CKD. American Journal of Kidney Diseases 2016;67(3):423-30.

8. Beto JA, Bansal VK. Medical nutrition therapy in chronic kidney failure: integrating clinical practice guidelines. J Am Diet Assoc 2004;104(3):404-9.

9. Chen M-E, Hwang S-J, Chen H-C, et al. Correlations of dietary energy and protein intakes with renal function impairment in chronic kidney disease patients with or without diabetes. The Kaohsiung Journal of Medical Sciences 2017;33(5):252-9.

10. Phukan, R. R., Goswami, R. K. Unusual dyslipidemia in patients with chronic kidney diseases. J Clin Diagn Res 2017; 11, BC01-BC04.

11. Krishnamurthy VMR, Wei G, Baird BC, et al. High dietary fiber intake is associated with decreased inflammation and all-cause mortality in patients with chronic kidney disease. Kidney Int 2012;81(3):300-6.

12. McMahon EJ, Campbell KL, Bauer JD, Mudge DW. Altered dietary salt intake for people with chronic kidney disease. Cochrane Database Syst Rev 2015;(2):CD010070.

13. McMahon EJ, Bauer JD, Hawley CM, et al. A randomized trial of dietary sodium restriction in CKD. J Am Soc Nephrol 2013;24(12):2096-103.

14. Diaconu CC, Manea M, Iancu MA, et al. Hyponatremia in patients with heart failure: a prognostic marker. Rev Chim 2018;69(5):1071-1074.

15. Diaconu CC, Stanescu AMA, Pantea Stoian A, et al. Hyperkalemia and cardiovascular diseases: new molecules for the treatment. Rev Chim 2018;69(6):1367-1370.

16. He J, Mills KT, Appel LJ, et al. Urinary sodium and potassium excretion and CKD progression. J Am Soc Nephrol 2016;27(4):1202-12.

17. O’Donnell M, Mente A, Rangarajan S, et al. Urinary sodium and potassium excretion, mortality, and cardiovascular events. N Engl J Med 2014;371(7):612-23.

18. Mehrotra R, Peralta CA, Chen S-C, et al. No independent association of serum phosphorus with risk for death or progression to end-stage renal disease in a large screen for chronic kidney disease. Kidney Int 2013;84(5):989-97.

19. Da J, Xie X, Wolf M, et al. Serum phosphorus and progression of CKD and mortality: a meta-analysis of cohort studies. American Journal of Kidney Diseases 2015;66(2):258-65.

20. Lin J, Fung TT, Hu FB, Curhan GC. Association of dietary patterns with albuminuria and kidney function decline in older white women. Am J Kidney Dis 2011;57(2):245-54.

21. Rebholz CM, Crews DC, Grams ME, et al. DASH diet and risk of subsequent kidney disease. Am J Kidney Dis 2016;68(6):853-61

22. Chrysohoou C, Panagiotakos DB, Pitsavos C, et al Adherence to the mediterranean diet is associated with renal function among healthy adults: the ATTICA study. Journal of Renal Nutrition 2010;20(3):176-84.

23. Khatri M, Moon YP, Scarmeas N, et al. The association between a mediterranean-style diet and kidney function in the Northern Manhattan Study cohort. CJASN 2014;9(11):1868-75.
24. Gutiérrez OM, Muntner P, Rizk DV, et al. Dietary patterns and risk of death and progression to ESRD in individuals with CKD: a cohort study. Am J Kidney Dis 2014;64(2):204-13.

25. Wai SN, Kelly JT, Johnson DW, Campbell KL. Dietary patterns and clinical outcomes in chronic kidney disease: the CKD.QLD Nutrition Study. Journal of Renal Nutrition 2017;27(3):175-82.

26. Gopinath B, Harris DC, Flood VM, Burlutsky G, et al. Carbohydrate nutrition is associated with the 5-year incidence of chronic kidney disease. J Nutr 2011;141(3):433-9.

27. Shankar A, Klein R, Klein BEK. The association among smoking, heavy drinking, and chronic kidney disease. Am J Epidemiol 2006;164(3):263-71.

28. Diaconescu D, Pantea Stoian A, Socea L, et al. Hepato-renal syndrome: a review. Arch Balk Med Union 2018;53(2):239-245.

29. Moroi I, Iancu MA, Stanescu AMA, et al. Alcohol withdrawal syndrome: a review. Modern Medicine 2018;25(2):65-68.

30. Menon V, Katz R, Mukamal K, et al. Alcohol consumption and kidney function decline in the elderly alcohol and kidney disease. Nephrol Dial Transplant 2010;25(10):3301-7.

31. Schaeffner ES, Kurth T, Jong PE et al. Alcohol consumption and the risk of renal dysfunction in apparently healthy men. Arch Intern Med 2005;165(9):1048-53.

32. Aparicio M, Chauveau P, De Précigout V, Bouchet JL, Lasseur C, Combe C. Nutrition and outcome on renal replacement therapy of patients with chronic renal failure treated by a supplemented very low protein diet. J Am Soc Nephrol 2000;11(4):708-16.

33. Bernhard J, Beaufrère B, Laville M, Fouque D. Adaptive response to a low-protein diet in predialysis chronic renal failure patients. J Am Soc Nephrol 2001;12(6):1249-54.

34. Cianciaruso B, Pota A, Pisani A, et al. Metabolic effects of two low protein diets in chronic kidney disease stage 4-5-a randomized controlled trial. Nephrol Dial Transplant 2008;23(2):636-44.

35. Bellizzi V, Di Iorio BR, De Nicola L, et al. Very low protein diet supplemented with ketoanalogs improves blood pressure control in chronic kidney disease. Kidney International 2007;71(3):245-51.

36. Chauveau P, Couzi L, Vendrely B, et al. Long-term outcome on renal replacement therapy in patients who previously received a keto acid-supplemented very-low-protein diet. Am J Clin Nutr 2009;90(4):969-74.

37. Piccoli GB, Ventrella F, Capizzi I, et al. Low-protein diets in diabetic chronic kidney disease (CKD) patients: are they feasible and worth the effort? Nutrients 2016;8(10).

38. Asghari G, Yuzbashian E, Mirmiran P, Azizi F. The association between Dietary Approaches to Stop Hypertension and incidence of chronic kidney disease in adults: the Tehran Lipid and Glucose Study. Nephrol Dial Transplant 2017;32(suppl_2):ii224-30.

39. Scialla JJ, Appel LJ, Astor BC, et al. Net endogenous acid production is associated with a faster decline in GFR in African Americans. Kidney Int 2012;82(1):106-12.

40. Díaz-López A, Bulló M, Martínez-González MÁ, et al. Effects of mediterranean diets on kidney function: a report from the PREDIMED trial. American Journal of Kidney Diseases 2012;60(3):380-9.

41. Bomback AS, Derebail VK, Shoham DA, et al. Sugar-sweetened soda consumption, hyperuricemia, and kidney disease. Kidney International 2010 ;77(7):609-16. 